\title{
Islamic Finance in Australia Interest or not interest, that is the question?
}

Associate Professor Justin Dabner

Law School, James Cook University, Cairns, Australia 


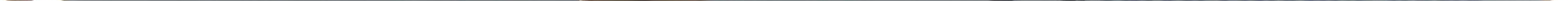




\section{Islamic Finance: Australia reacts belatedly. And impetuously?}

\section{Introduction}

$>$ The growth of Islamic Finance

$>$ The Shariah

$>$ The prohibitions

$>$ The structures

$>$ The tax implications

$>$ The opportunity

$>$ The Australian response 


\section{KEY PRINCIPLES UNDERLYING ISLAMIC FINANCE}

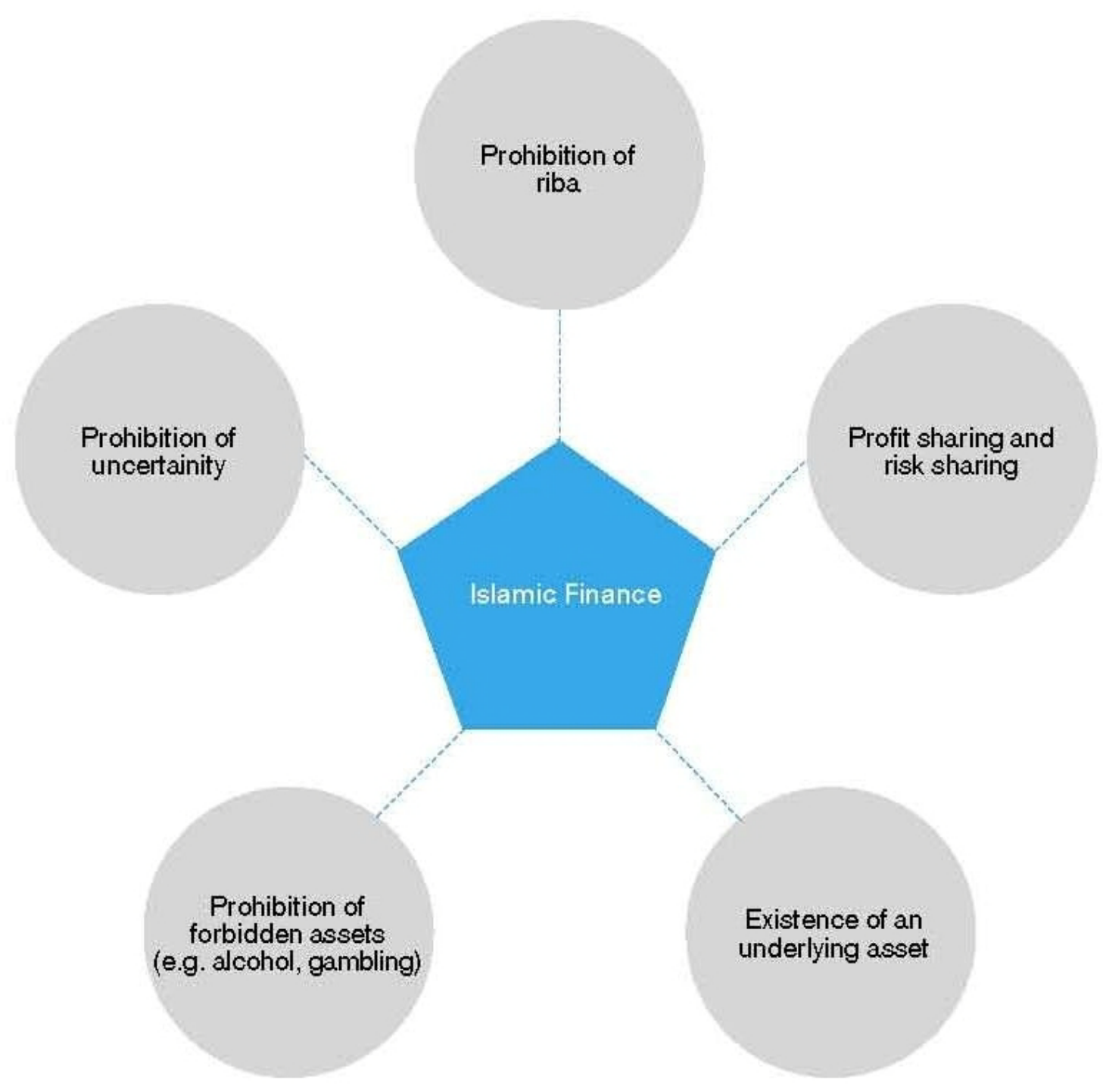

'Islamic Trade' - Austrade (austrade.gov.au) 


\section{The Shariah and finance structures}

$>$ Murabaha (cost plus)

$>$ Mudharabah (profit sharing limited partnership)

$>$ Ijara wa-igtina (lease-purchase)

$>$ Musharakah (joint venture) and sukuk

(securitization) 


\section{MURABAHA MECHANISM}

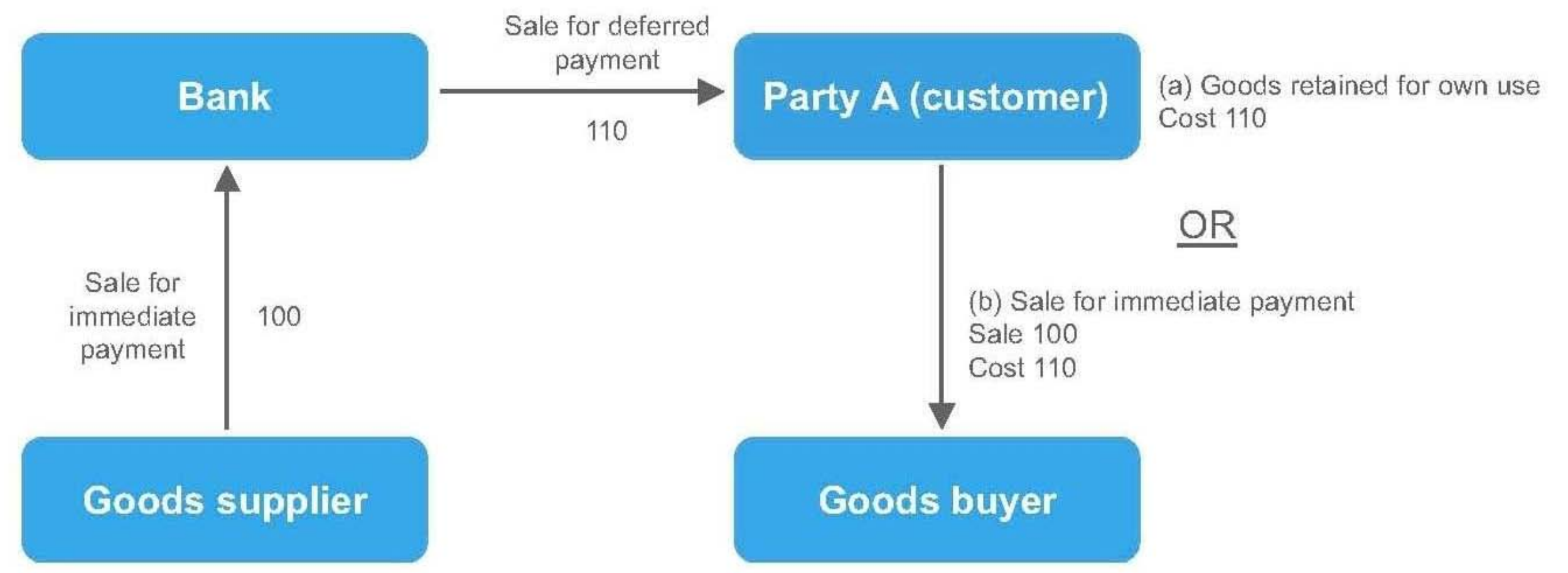

Source: PwC UK 
MUDARABA MECHANISM

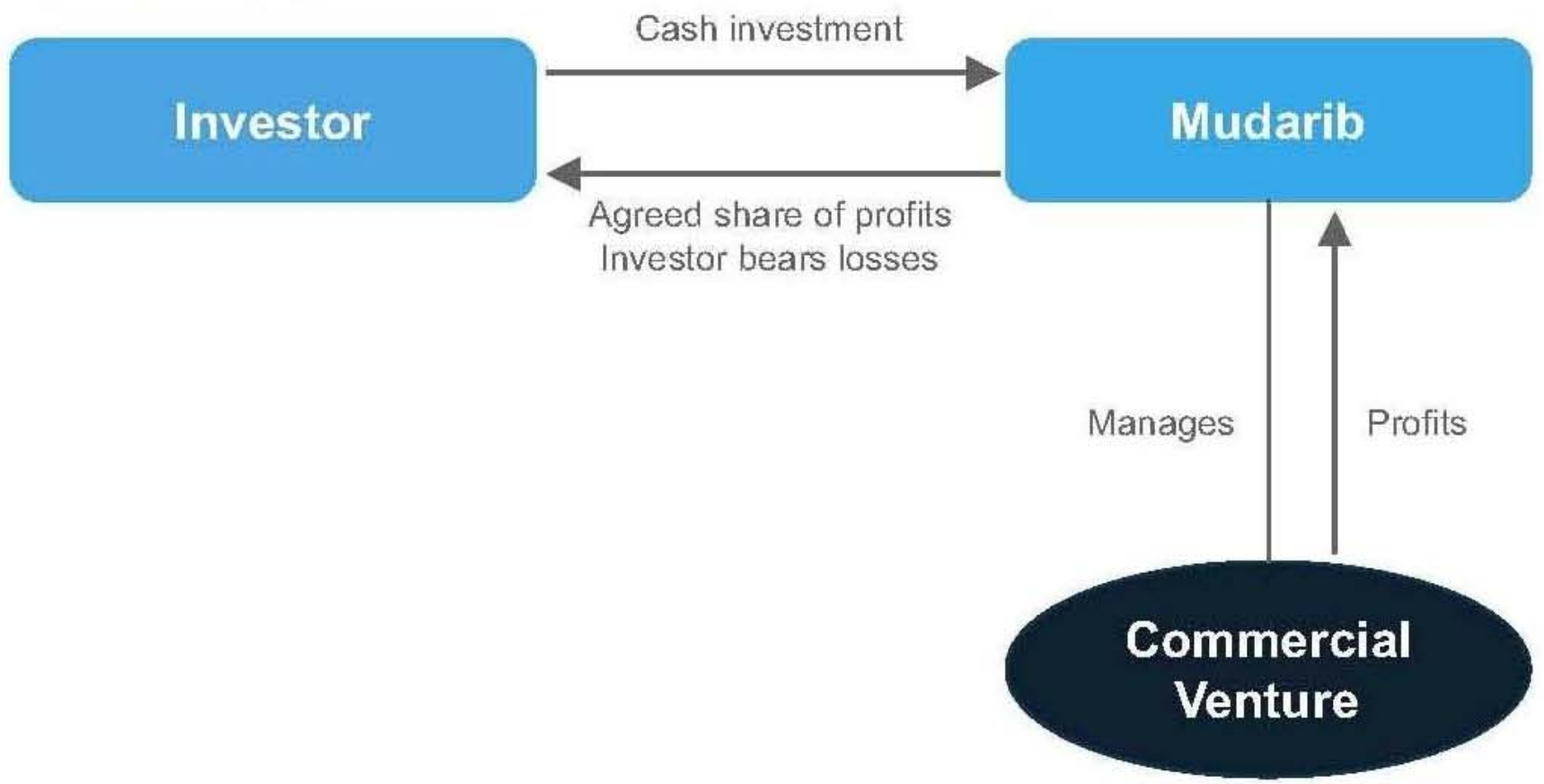

Source: Amin, M and Suleman, I, 'Islamic Finance: The Tax Adviser's Role', Tax Adviser, September 2008

'Islamic Trade' - Austrade (austrade.gov.au) 


\section{IJARA SUKUK}

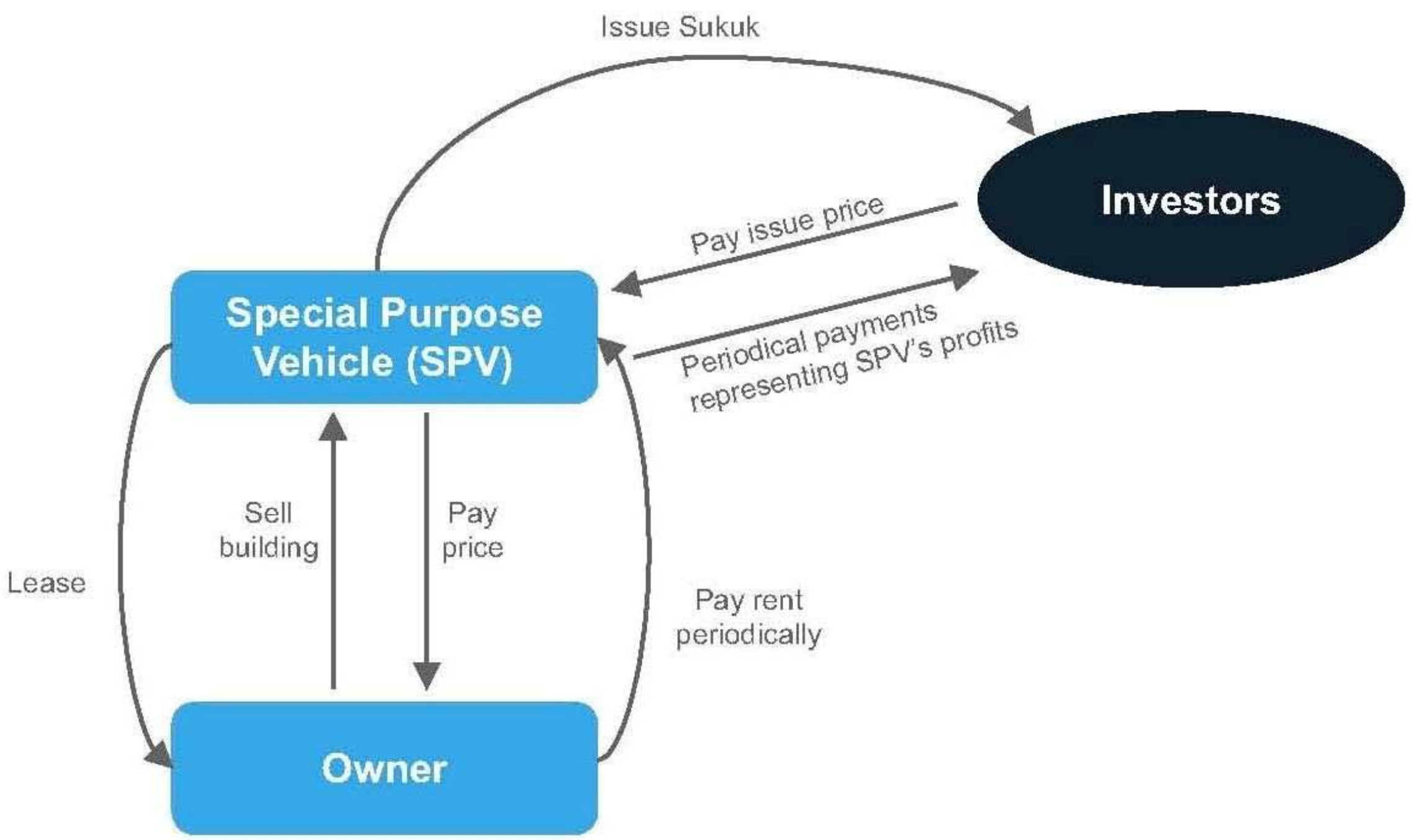




\section{DIMINISHING MUSHARAKA TRANSACTION WITH 25 PER CENT DEPOSIT}

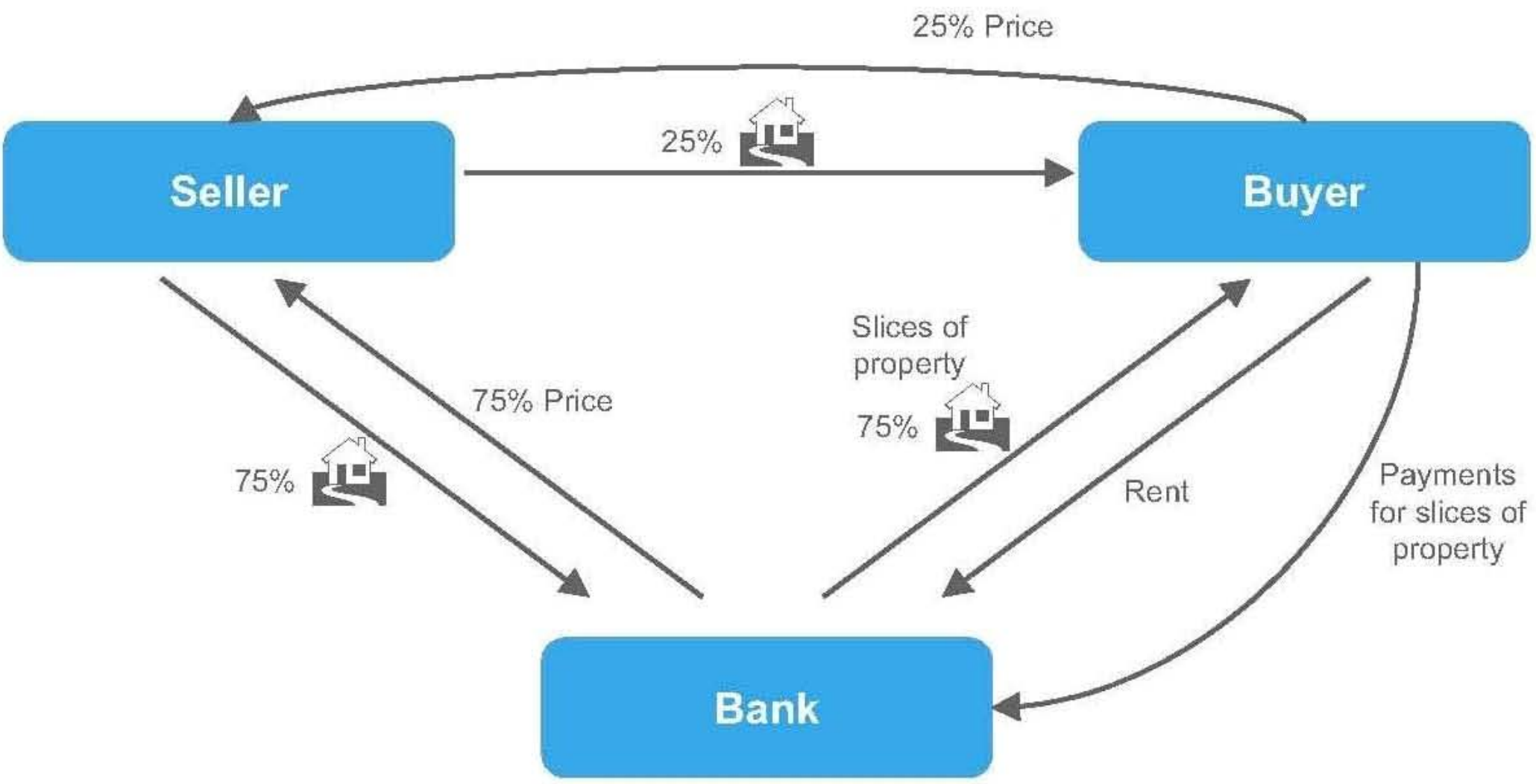

Source: Amin, M and Suleman, I, 'Islamic Finance: The Tax Adviser's Role', Tax Adviser, September 2008 


\section{Tax implications of Islamic finance}

$>$ Stamp duty

$>$ GST/VAT

$>\mathrm{CGT}$

$>$ Income tax 


\section{Responses by other countries}

$>$ Malaysia

oPositive discrimination

$>$ United Kingdom

oNo special favours 


\section{Islamic finance in Australia}

$>$ Australian tax implications of Islamic finance

$>$ Inward Islamic foreign investment

$>$ Developments in Australia

o2004 Victorian stamp duty amendments

o2009 Financial Centre Forum report

o2010 Australian Trade Commission report

o2010 Board of Taxation Discussion paper 


\section{Critique of the Australian response: threshold questions}

$>$ In substance interest or in lieu of interest?

$>$ Should Australia cater for Islamic finance?

oThe Islamic interest / The national interest

$>$ Are reforms benefitting one religious group permissible?

$>$ Should artificial / complex financial arrangements be endorsed? 


\section{Critique of the Australian response: threshold questions (cont'd)}

$>$ Are tax concessions a desirable policy tool?

$>$ Acceptability of tax integrity risks?

$>$ How significant is Islamic finance?

$>$ Is tax important to Islamic financiers?

$>$ 'Level playing field`concession or global finance centre? 


\section{Conclusion}

$>$ Reform process failure? 